\title{
The Role of Penicillinase in Determining Natural and Acquired Resistance of Gram-Negative Bacteria to Penicillins
}

\author{
By A. PERCIVAL, W. BRUMFit' and J. De LOUVOIS \\ From the Department of Bacteriology, Edgware General Hospital, Edgware, \\ Middlesex and the Wright-Fleming Institute of Microbiology, \\ St Mary's Hospital London, W. 2
}

(Received 3 December 1962)

\begin{abstract}
SUMMARY
The development of resistance to ampicillin (aminophenylacetamidopenicillanic acid) and penicillin $G$ was investigated by selecting resistant variants of strains of Escherichia coli. Resistance occurred in stepwise manner. The parent strains contained minute amounts of penicillinase and production of the enzyme by resistant variants increased in relation to increase in resistance. Evidence was obtained that production of penicillinase was responsible for this increase in resistance. By using resistant variants and naturally occurring ampicillin-resistant organisms, it was found that production of only small amounts of penicillinase was sufficient to confer a high degree of resistance to the Gram-negative bacteria examined. In contrast, Gram-positive bacteria required much greater quantities of penicillinase for high grade resistance. It is suggested that an important reason for this difference is the complex lipid-containing cell wall of Gram-negative bacteria, which slows penetration by penicillin and enables small amounts of penicillinase to protect the cell. The penicillinase of all the Gram-negative organisms investigated was found to be a $\beta$-lactamase and to be more active against penicillin $\mathbf{G}$ than against ampicillin. This provides one explanation for the greater activity of ampicillin against Gram-negative bacteria.
\end{abstract}

\section{INTRODUCTION}

Since the isolation of 6-aminopenicillanic acid (Batchelor, Doyle, Nayler \& Rolinson, 1959) many new penicillins have been synthesized. One of these, aminophenylacetamidopenicillanic acid (ampicillin) is of theoretical and therapeutic importance because it is much more active against several Gram-negative bacteria than is penicillin $\mathbf{G}$ (Rolinson \& Stevens, 1961). In preliminary studies a wide range of Gram-negative bacteria were examined for sensitivity to ampicillin and penicillin G. It was found that those organisms sensitive to ampicillin were also invariably sensitive to penicillin $G$, although the minimum inhibitory concentration for penicillin $\mathrm{G}$ was always 5 to 10 times greater than that for ampicillin. Similarly, Gram-negative bacteria highly resistant to ampicillin were always highly resistant to penicillin G. It has recently been demonstrated that, like penicillin $G$, ampicillin inhibits the incorporation of cytoplasmic cell wall precursors (Rogers \& Mandlestam, 1962) and we have observed that ampicillin causes cytological changes in Gram- 
negative bacteria similar to those produced by the action of penicillin G (Duguid, 1946; Hughes, Kramer \& Fleming, 1946; Lederberg, 1957). It seemed reasonable to assume, therefore, that the mode of action of ampicillin is similar to that suggested by Park \& Strominger (1957) for penicillin G, namely, to interfere with cell wall synthesis by preventing the formation and incorporation of muramic acidpeptide. It has long been known that Gram-negative bacteria may produce penicillinase (Abraham \& Chain, 1940) and in the present work we have studied the part played by this enzyme in determining natural and acquired resistance to penicillins. Our findings have enabled us to suggest reasons for the relatively greater activity of ampicillin than other penicillins against Gram-negative bacteria.

\section{METHODS}

Media. Nutrient broth was made of Lab-Lemco meat extract $0 \cdot 1 \%(\mathrm{w} / \mathrm{v})$, Tryptone (Oxoid) $\mathbf{0 . 2} \%$ (w/v), peptone (Oxoid) $1 \%$ (w/v), $\mathrm{NaCl} 0.7 \%(\mathrm{w} / \mathrm{v}$ ). Nutrient agar contained nutrient broth solidified with $1.5 \%(\mathrm{w} / \mathrm{v})$ Davis New Zealand agar.

Organisms. Standard laboratory strains of Escherichia coli (designated c $3, \mathrm{cv}$, $\mathrm{k} 28$ ) were used in many of the experiments. The characteristics of these organisms were described in detail previously (Brumfitt \& Heptinstall, 1960). A number of other Gram-negative bacteria isolated from patients with acute urinary infections, and penicillinase-producing staphylococci from infected lesions, were also used. Cultures of bacteria were preserved on agar slopes at $4^{\circ}$.

Penicillins. Penicillin G was obtained from Glaxo Laboratories Ltd. (Greenford, Middlesex) and methicillin, ampicillin, 6-aminopenicillanic acid (6-APA) and 3o-chlorophenyl-5-methyl-4-isoxazolyl penicillin (BRL 1621) from Beecham Research Laboratories (Brockham Park, Surrey). BRL 1621 is one of the isoxazolyl series of penicillins (Doyle, Long, Nayler \& Stove, 1961) which combines the properties of penicillinase resistance with acid stability (Knudsen, Brown \& Rolinson, 1962).

Standard penicillinases. Bacillus cereus penicillinase (Distillers Company Ltd., London) was used as a source of $\beta$-lactamase. A thick toluene-killed suspension of an amidase-producing coliform organism was kindly supplied by Dr F. R. Batchelor (Beecham Research Laboratories). This enzyme was stable when stored at $4^{\circ}$ and was used as a standard amidase preparation.

Sensitivity testing. Screening tests for selection of naturally occurring ampicillinresistant organisms were carried out by placing dried impregnated paper dises on well-dried nutrient agar plates previously flooded with a log-phase bacterial culture. In order to standardize the inoculum the optical density of the bacterial culture was measured in the Hilger absorptiometer and the culture then diluted so as to give a bacterial count of about $10^{6}$ organisms per ml. Ampicillin (25 $\mu \mathrm{g}$./disc) was used and an organism was considered to be resistant when there was no zone of inhibition after incubation for $18 \mathrm{hr}$. at $37^{\circ}$.

The minimum inhibitory concentration (MIC) for a particular organism was determined by adding a standard inoculum (about $10^{4}$ bacteria) of mid log-phase culture to tubes containing serial dilutions of the antibiotic in broth. The lowest concentration of antibiotic which completely inhibited growth as judged by the absence of turbidity after incubation for $18 \mathrm{hr}$. at $37^{\circ}$ was taken to be the MIC. 
Selection of resistant variants. Resistant variants of ampicillin-sensitive strains were selected by serial subculture on nutrient agar containing increasing concentrations of ampicillin. At the same time the mutational frequency for selection of variants at a particular concentration of ampicillin was calculated by comparing the number of colonies on the ampicillin-containing medium with a viable count carried out by preparing tenfold dilutions of the bacterial suspension and inoculating antibiotic-free medium. For comparison with the ampicillin-resistant variants, penicillin G-resistant variants of the parent strains were selected by the same technique.

\section{Detection and estimation of penicillinase production}

Screening tests for penicillinase production were made on broth cultures which were incubated for 6-18 hr. at $37^{\circ}$ when the test organism was killed by the addition of toluene to a final concentration of $10 \%(\mathrm{v} / \mathrm{v})$. These killed cultures were incubated with penicillin $\mathbf{G}$ for periods of $1-4 \mathrm{hr}$. at $37^{\circ}$ and the residual penicillin was then assayed by the microbiological cup-plate method with Sarcina lutea (ATCC 9341) as test organism. This method was also used to compare the susceptibilities of penicillin G, ampicillin, methicillin, BRL 1621 and 6-APA to the penicillinases produced by various bacterial strains. Of the penicillins tested penicillin $\mathbf{G}$ was found to be the most susceptible to Gram-negative penicillinases and therefore was used as substrate for their estimation.

To compare the penicillinase activities of different preparations more accurately than was possible by the method described above, several procedures were tried, including that of Perret (1954), the spectrophotometric assay as described by Saz, Lowery \& Jackson (1961), the method of Haight \& Finland (1952) and a microassay method based upon that described by Pollock (1957). The micro-assay method was the only one which allowed small amounts of penicillinase to be measured sufficiently accurately for our purposes and will be described.

A sample $(2 \mathrm{ml}$.) of penicillinase solution was added to $8 \mathrm{ml}$. of nutrient broth containing penicillin G $20 \mu \mathrm{g} . / \mathrm{ml}$., and the mixture incubated at $37^{\circ}$. At intervals of 15 or 30 min., samples $(1 \mathrm{ml}$.) were withdrawn, diluted with $9 \mathrm{ml}$. of ice-cold $0.01 \mathrm{~m}$-potassium phosphate buffer $(\mathrm{pH} \mathrm{7.0})$ and the residual penicillin assayed in triplicate by the cup-plate assay with Sarcina lutea as test organism, and comparing zones of inhibition with those obtained using standard penicillin $\mathbf{G}$ solutions over the range $\mathbf{0} \cdot \mathbf{2 5 - 2 \cdot 0} \mu \mathrm{g} . / \mathrm{ml}$. Assay plates were kept at $4^{\circ}$ for $2-4 \mathrm{hr}$. before overnight incubation at $37^{\circ}$. Penicillin was estimated without the need for a specific penicillinase inactivator, because of the decrease of enzyme activity on sampling due to lowering of the temperature to $0^{\circ}$ and the 1 in 10 dilution of substrate (Pollock, 1957). Penicillinase activity was estimated in terms of the rate of inactivation of penicillin $\mathrm{G}$ under standard conditions. This measurement was made from a graph in which residual penicillin was plotted against time.

\section{Relationship between penicillin resistance and penicillinase production}

The relationship between penicillinase production and resistance to penicillins was first demonstrated by comparing the MIC value obtained for ampicillin and penicillin $\mathrm{G}$ with large inocula (about $10^{6}$ bacteria) with the values obtained with small 
inocula (about 100 bacteria). By using the micro-assay method described, we subsequently carried out more accurate estimations of penicillinase activity with Seitz (SB) filtrates of 6-18 hr. broth cultures of Escherichia coli $\mathrm{cv}$ and its resistant variants. Preliminary experiments showed that there was no appreciable adsorption of this Gram-negative penicillinase by Seitz (SB) pads.

\section{Determination of cell-bound and extracellular penicillinase}

The organism to be tested was incubated for $18 \mathrm{hr}$. at $37^{\circ}$ in $500 \mathrm{ml}$. nutrient broth. The bacteria were then deposited by centrifugation at $3000 \mathrm{rev} . / \mathrm{min}$. for 20 min. and the supernatant fluid passed through a Seitz (SB) filter. The penicillinase activity of the filtrate was then estimated; this was taken to represent extracellular penicillinase.

In order to remove any remaining traces of extracellular penicillinase from the bacterial deposit it was then washed three times by centrifugation in $0.01 \mathrm{M}$-phosphate buffer $(\mathrm{pH} 7 \cdot 0)$ at $4^{\circ}$ and resuspended in distilled water. Similar viable counts were obtained before and after this treatment, showing that no appreciable lysis of bacteria had occurred. The washed suspension was then divided into two equal portions. One was treated with toluene to prevent further bacterial growth. The other portion was treated in the Mullard ultrasonic $2 \mathrm{~kW}$. disintegrator for $30 \mathrm{~min}$., the suspension divided and half of it centrifuged at $27,000 \mathrm{rev} . / \mathrm{min} .(65,900 \mathrm{~g})$ for $20 \mathrm{~min}$. and the supernatant removed. The penicillinase activity of the toluene treated bacteria, the suspension of disintegrated bacteria and the supernatant fluid from the suspension of disintegrated bacteria was then estimated. To see whether the ultrasonic treatment used to disintegrate the bacteria did not also inactivate the penicillinase liberated, a Seitz filtrate of a broth culture containing penicillinase was subjected to treatment in the ultrasonic disintegrator. Treatment identical with that needed to break the bacteria caused no detectable loss of penicillinase activity. It was also found that the addition of toluene to a Seitz filtrate containing Gramnegative penicillinase had no effect on the activity of the enzyme.

Induction of penicillinase. Tests for inducibility of penicillinase were carried out in broth cultures of Escherichia coli $\mathrm{cv}$ and resistant variants of it which had been incubated for $6-10 \mathrm{hr}$. at $37^{\circ}$. In different experiments either ampicillin, penicillin G, methicillin or BRL 1621 was added to make a final concentration of $0.5-$ $2 \cdot 0 \mu \mathrm{g}$. $/ \mathrm{ml}$. and incubation at $37^{\circ}$ then continued for a further 1-8 hr. Penicillinase activity was estimated in the whole broth culture after the addition of toluene and in the filtrate after Seitz filtration. As a control for basal penicillinase activity estimations were performed in parallel on broth cultures to which no penicillin had been added.

Identification of penicillinase. Penicillinases are either $\beta$-lactamases or amidases (Rolinson et al. 1960). The distinction between these two enzymes was based upon the finding that the 6-aminopenicillanic acid (6-APA) formed following the action of amidase on penicillin can readily be converted into penicillin $\mathrm{G}$ by simple chemical treatment (Batchelor et al. 1959), whereas the penicilloic acid formed by the action of $\beta$-lactamase cannot.

An overnight broth culture of the organism to be tested was incubated for 1-4 hr. with a known amount of penicillin $G$ and a sample withdrawn for assay of residual penicillin by the cup-plate method. To convert any 6-APA to penicillin G, 
anhydrous sodium bicarbonate and $10 \%(\mathrm{v} / \mathrm{v})$ phenylacetyl chloride (British Drug Houses Ltd.) in dry acetone were added to the rest of the culture to give final concentrations of $3 \%(\mathrm{w} / \mathrm{v})$ and $1 \%(\mathrm{v} / \mathrm{v})$, respectively. This mixture was allowed to stand at room temperature for $15 \mathrm{~min}$. and the penicillin $\mathrm{G}$ content then assayed as before. Failure to demonstrate increase in penicillin after reconstitution was taken to indicate that the penicillinase was a $\beta$-lactamase. The validity of this assumption was confirmed by testing several penicillinase-producing strains for ability to act upon 6-APA, which is inactivated by $\beta$-lactamase but not by amidase. Broth cultures of several penicillinase-producing strains were incubated with known amounts of 6-APA and the extent of inactivation estimated by reconstitution of residual 6-APA to penicillin $\mathrm{G}$.

Antisera. O antisera to the standard Escherichia strains were prepared by the method described by Edwards \& Ewing (1957).

Pathogenicity tests. A comparison was made between Escherichia coli cv parent strain and a resistant variant with an MIC of $2500 \mu \mathrm{g} . / \mathrm{ml}$. ampicillin. Four separate experiments were carried out in which groups of five mice (18-20 g.) received an intraperitoneal injection of $0 \cdot 1 \mathrm{ml}$. bacterial suspension containing $10^{8}, 10^{6}, 10^{4}$ and $10^{2}$ log-phase bacteria. Each batch of five mice was housed in a separate cage and the mortality was determined 4 days after inoculation. All results were used in the final analysis. LD 50 values were calculated by the method of Reed \& Muench (1938). Bacterial suspensions were made in saline and in every case viable counts were carried out.

\section{RESULTS}

\section{Selection of resistant variants of Escherichia coli in the laboratory}

Escherichia coli variants resistant to penicillin $\mathbf{G}$ and to ampicillin were selected without difficulty with the three Escherichia strains cv, c3 and $\mathrm{k} 28$. Resistance developed in a stepwise fashion; variants were selected most readily from strain $\mathrm{cv}$. The parent strain (CVP) of this organism had an MIC of $7 \cdot 5 \mu \mathrm{g}$. ampicillin $/ \mathrm{ml}$., but after only three subcultures in the presence of increasing concentrations of ampicillin a resistant variant with an MIC of $400 \mu \mathrm{g}$. ampicillin $/ \mathrm{ml}$. (strain CVR 400) was obtained and after six subcultures a resistant organism with an MIC of $2500 \mu \mathrm{g}$. ampicillin/ml. (strain CVR 2500) was selected. The greatest single step increase in resistance to both ampicillin and penicillin $\mathbf{G}$ by $\boldsymbol{E}$. coli strain $\mathrm{CV}$ was tenfold, and the mutational frequency for selection of resistant mutants with ten times the resistance of the parent strain was about $1 / 10^{8}$ bacteria. With strains $\mathrm{c} 3, \mathrm{k} 28$ and others, increase in resistance occurred in smaller steps, but the mutational frequency for selection of resistant mutants was similar. Investigation of a number of parent strains and their resistant variants showed no differences in colonial appearance, biochemical reactions, agglutination by specific $\mathrm{O}$ antisera, growth curves or mouse pathogenicity. Resistant mutants were stable and no significant change in resistance was detected after twenty subcultures on antibiotic-free medium.

\section{Cross-resistance}

Table 1 compares the MIC values obtained with three penicillins by using Escherichia coli cv parent strain (CVP) and two resistant variants (CVR 400, CVR 2500) 
as test organisms. These variants had been selected by subculture in the presence of ampicillin, but it can be seen (Table 1) that there was complete cross-resistance with penicillin G. Similarly a variant of strain cv selected by growth in presence of penicillin G showed cross-resistance to ampicillin. When the MIC values of $E$. coli $\mathrm{cv}$ to ampicillin and penicillin $\mathrm{G}$ are expressed as a ratio this is very similar for the parent organism and for its resistant variants (Table 1). This ratio was approximately the same whether ampicillin or penicillin $G$ was used for the selection of the variants. The numerous organisms tested and found to be naturally resistant to ampicillin were also always resistant to penicillin $\mathrm{G}$. This shows that the difference between resistance of these bacteria to ampicillin and penicillin $\mathbf{G}$ is quantitative rather than qualitative. In contrast, the factors responsible for resistance of variants to ampicillin and penicillin $\mathbf{G}$ did not cause increased resistance to antibiotic BRL 1621, although in this case the parent strain was itself highly resistant (Table 1).

Table 1. Antibacterial activity of different penicillins against resistant variants of Escherichia coli strain $\mathrm{cV}$

\begin{tabular}{|c|c|c|c|c|}
\hline \multirow[b]{2}{*}{ Organism } & \multicolumn{3}{|c|}{$\begin{array}{l}\text { Minimum inhibitory concentration } \\
\text { (MIC } \mu \mathrm{g} . / \mathrm{ml} .)\end{array}$} & \multirow{2}{*}{$\begin{array}{l}\text { Ratio MIC } \\
\text { ampicillin to } \\
\text { penicillin G }\end{array}$} \\
\hline & Penicillin G & Ampicillin & BRL 1621 & \\
\hline CV parent strain (CVP) & 30 & $7 \cdot 5$ & 450 & $1: 4$ \\
\hline Ampicillin-resistant variants of $\mathrm{cv}$ & & & & \\
\hline CVR 400 & 1400 & 400 & 450 & $1: 3 \cdot 5$ \\
\hline CVR 2500 & 9000 & 2500 & 450 & $1: 3 \cdot 6$ \\
\hline Penicillin G-resistant variant of $\mathrm{CV}$ & $\mathbf{7 5 0}$ & 200 & 450 & $1: 3 \cdot 7$ \\
\hline
\end{tabular}

\section{Production of penicillinase by resistant variants}

During the initial stages of selection of ampicillin-resistant variants of Escherichia coli $\mathrm{cv}$ it was found that when the concentration of ampicillin added to the nutrient agar just exceeded the MIC value for the parent strain, some of the resistant variants selected were surrounded by small satellite colonies. The MIC value of ampicillin for the colonies which were surrounded by satellites was much higher than that for the parent strain, whereas the MIC value for the satellite colonies was the same as for the parent strain. This suggested that the resistant variants of strain $\mathrm{cv}$ were producing penicillinase. This was confirmed by the screening test for penicillinase production: penicillinase activity shown in broth cultures of resistant variants of all three laboratory strains of $E$. coli (cv, c 3, k28), but not in cultures of the parent strains.

Variants selected by subculture in the presence of ampicillin or penicillin G produced penicillinase, but the enzyme was much more active against penicillin $G$. For this reason penicillin $\mathrm{G}$ was always used as substrate when accurate estimations of penicillinase activity were required. This was necessary because even highly resistant variants produced only small amounts of penicillinase. For example, $1 \mathrm{ml}$. of an $18 \mathrm{hr}$. broth culture of the variant strain cVR 400, which had an MIC of $400 \mu \mathrm{g}$. ampicillin $/ \mathrm{ml}$. and $1400 \mu \mathrm{g}$. penicillin $\mathrm{G} / \mathrm{ml}$., inactivated only $2 \mu \mathrm{g}$. ampicillin and $50 \mu \mathrm{g}$. penicillin $\mathbf{G}$ after $1 \mathrm{hr}$. at $37^{\circ}$. However, production of small amounts of penicillinase could regularly be correlated with a high degree of resistance.

The ampicillin-resistant variant (strain CVR 400) was grown in nutrient broth at 
$37^{\circ}$. Samples were removed at hourly intervals and the bacteria removed by Seitz (SB) filtration. Estimation of the penicillinase activity of the filtrate by the microassay method showed a progressive increase between 4 and $10 \mathrm{hr}$. A comparison was also made between the amount of penicillinase present in whole cultures and the amount present in a Seitz filtrate of the same culture. Estimations were made at hourly intervals and it was found that the filtrate had a penicillinase activity only about $10 \%$ less than the whole culture. This was true even at $4 \mathrm{hr}$. when the penicillinase concentration began to increase. Experiments with the ampicillinresistant variant cVR 2500 gave similar results.

\section{Relationship between penicillin resistance and penicillinase production}

Estimation of the penicillinase activities of variants of Escherichia coli strain cv with increasing degrees of resistance to ampicillin, showed that the degree of resistance was proportional to the amount of penicillinase produced (Table 2). The

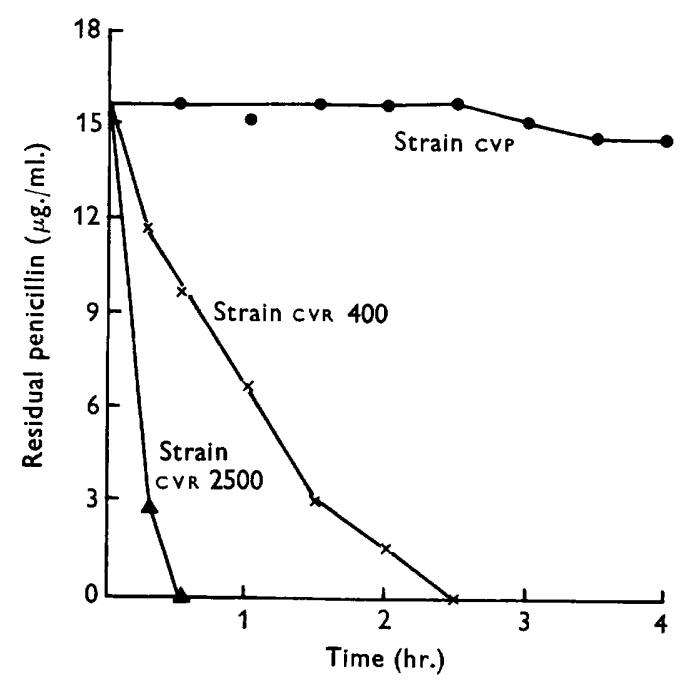

Fig. 1. Penicillinase activity in Escherichia coli strain $\mathrm{cv}$ and resistant variants (cve 400, CVR 2500) with M.I.C. values of 400 and $2500 \mu \mathrm{g}$. ampicillin $/ \mathrm{ml}$., respectively.

relationship between penicillinase production and resistance is also shown in Fig. 1, in which $\mathrm{Cv}$ parent strain and the two resistant variants CVR 400 and CVR 2500 were used. These three organisms grown under identical conditions in nutrient broth were subsequently shown to contain similar numbers of bacteria. The actual experiment was carried out on Seitz filtrates of these cultures.

It was possible to show penicillinase activity in the same resistant variants (cVR 400, cVR 2500) by using the spectrophotometric method of Saz et al. (1961) and by the method of Haight \& Finland (1952). Indications of differences in the penicillinase activities in variants with increasing degrees of resistance were observed. However, such differences could not be measured as precisely as by the micro-assay method. No penicillinase activity was detected in the parent strain or in variants with lower degrees of resistance. By using the micro-assay procedure 
and a heavy suspension of bacteria (equiv. $13.8 \mathrm{mg}$. dry wt./ml.) which had been subjected to ultrasonic disintegration, we consistently found traces of penicillinase activity in the parent strain CVP.

Table 2. Antibacterial activity of ampicillin and penicillinase activity in bacteria with natural and acquired resistance

\begin{tabular}{|c|c|c|c|}
\hline & $\begin{array}{c}\text { MIC } \\
\text { ampicillin } \\
(\mu \mathrm{g} . / \mathrm{ml} .)\end{array}$ & $\begin{array}{l}\text { Penicillinase } \\
\text { activity }(\mu \mathrm{g} . \\
\text { penicillin G } \\
\text { inactivated in } \\
\left.1 \mathrm{hr} \text {. at } 37^{\circ}\right)\end{array}$ & $\begin{array}{l}\text { Ratio of minimum } \\
\text { inhibitory con- } \\
\text { centration to } \\
\text { penicillinase } \\
\text { activity }\end{array}$ \\
\hline $\begin{array}{l}\text { Escherichia coli } \\
\text { Cv parent strain (CVP) } \\
\text { Ampicillin-resistant variants of strain cv }\end{array}$ & 7.5 & $<\mathbf{1 . 0}$ & $>7 \cdot 5: 1$ \\
\hline $\begin{array}{l}\text { CVR } 400 \\
\text { CVR } 2500\end{array}$ & $\begin{array}{r}400 \\
2500\end{array}$ & $\begin{array}{r}50 \\
150\end{array}$ & $\begin{array}{r}8: 1 \\
16 \cdot 6: 1\end{array}$ \\
\hline $\begin{array}{l}\text { Naturally resistant organisms } \\
\text { Aerobacter aerogenes (i) } \\
\text { (ii) }\end{array}$ & $\begin{array}{r}900 \\
50\end{array}$ & $\begin{array}{l}75 \\
5 \cdot 5\end{array}$ & $\begin{array}{r}12 \cdot 0: 1 \\
9 \cdot 1: 1\end{array}$ \\
\hline $\begin{array}{ll}\text { Escherichia coli } & \text { (i) } \\
& \text { (ii) }\end{array}$ & $\begin{array}{r}550 \\
50\end{array}$ & $\begin{array}{l}40 \\
4 \cdot 5\end{array}$ & $\begin{array}{l}13 \cdot 8: 1 \\
11 \cdot 1: 1\end{array}$ \\
\hline Proteus spp. & $\begin{array}{l}750 \\
300\end{array}$ & $\begin{array}{l}50 \\
12 \cdot 5\end{array}$ & $\begin{array}{l}15 \cdot 0: 1 \\
24 \cdot 0: 1\end{array}$ \\
\hline $\begin{array}{r}\text { Pseudomonas aeruginosa (i) } \\
\text { (ii) }\end{array}$ & $\begin{array}{r}500 \\
50\end{array}$ & $\begin{array}{c}25 \\
3 \cdot 5\end{array}$ & $\begin{array}{l}20 \cdot 0: 1 \\
14 \cdot 3: 1\end{array}$ \\
\hline Staphylococcus aureus & 250 & 100 & $2 \cdot 5: 1$ \\
\hline
\end{tabular}

Table 3. Antibacterial activity of different penicillins when using large or small inocula

\begin{tabular}{|c|c|c|c|}
\hline & \multirow{2}{*}{$\begin{array}{c}\text { No. of } \\
\text { bacteria in } \\
\text { inoculum }\end{array}$} & \multicolumn{2}{|c|}{$\begin{array}{c}\text { Minimum inhibitory concentratior } \\
(\mu \mathrm{g} . / \mathrm{ml} .)\end{array}$} \\
\hline & & Penicillin G & Ampicillin \\
\hline \multirow{3}{*}{$\begin{array}{l}\text { Escherichia coli } \\
\text { Cv parent strain (CvP) }\end{array}$} & & & \\
\hline & $10^{6}$ & 65 & 10 \\
\hline & $10^{2}$ & 25 & 5 \\
\hline \multicolumn{4}{|c|}{ Ampicillin-resistant variants of $\mathrm{cv}$} \\
\hline \multirow[t]{2}{*}{ CVR 400} & $10^{6}$ & 1,500 & 600 \\
\hline & $10^{2}$ & 900 & 350 \\
\hline \multirow[t]{2}{*}{ CVR 2500} & $10^{6}$ & 12,000 & 2,750 \\
\hline & $10^{2}$ & 7,000 & 2,250 \\
\hline \multirow[t]{2}{*}{ Staphylococcus aureus } & $10^{6}$ & 250 & 200 \\
\hline & $10^{2}$ & $7 \cdot 5$ & 10 \\
\hline
\end{tabular}

It can be seen in Table 3 that the size of inoculum produced only a small effect on the MIC values for the Cr parent strain and two of its resistant variants (CvR 400, CVR 2500) when tested against penicillin G and ampicillin. Although in every case the MIC value was higher with an inoculum of $10^{6}$ organisms than with $10^{2}$ organisms, this effect was small as compared with that found with a penicillinase-producing strain of Staphylococcus aureus (Table 3). The difference in inoculum effect for S. aureus and Escherichia coli strain CvR $\mathbf{4 0 0}$ was shown in another way. Samples $(0.02 \mathrm{ml}$.) of serial tenfold dilutions of washed cultures of these organisms were 
dropped on to nutrient agar containing $200 \mu \mathrm{g}$. ampicillin $/ \mathrm{ml}$. With the staphylococcus growth was only possible with a large inoculum, whereas with $\boldsymbol{E}$. coli cvR 400 growth occurred from a small inoculum, giving rise to single colonies.

\section{Proportion of cell-bound to extracellular penicillinase}

With Escherichia coli strains CVR 400 and CVR 2500, penicillinase activity in Seitz-filtrates was found to be $90 \%$ of that of the whole bacterial cultures in broth, the remaining $10 \%$ being detected in the washed bacterial suspensions.

The penicillinase activity of the washed bacterial suspensions was found to be $2 \cdot 5$ times greater after ultrasonic disintegration than before. This increase in activity following disintegration was taken to represent bound intracellular penicillinase, because the increase was unaffected by removal of the bacterial cell walls by centrifugation at $27,000 \mathrm{rev} . / \mathrm{min}$. Therefore, even allowing for bound intracellular penicillinase, in whole broth cultures of the two strains tested, about $75 \%$ of the total penicillinase was extracellular.

\section{Inducibility of penicillinase}

With Escherichia coli parent strain $\mathrm{CV}$ and the two resistant variants CVR 400 and CVR 2500, no increase in penicillinase activity was detected after attempted induction with the four penicillins used. In fact, when induction was attempted with the penicillinase-resistant penicillins, methicillin and BRL 1621, a progressive fall in penicillinase activity was observed, although the concentration of penicillin was too low to inhibit growth. There was no significant fall in penicillinase activity when ampicillin or penicillin $\mathrm{G}$ was used.

Table 4. Ampicillin resistance and penicillinase production in Gram-negative bacteria isolated from patients with urinary tract infections

\begin{tabular}{|c|c|c|c|c|}
\hline Organism & $\begin{array}{c}\text { No. of } \\
\text { isolates } \\
\text { tested }\end{array}$ & $\begin{array}{l}\text { No. isolates } \\
\text { resistant to } \\
\text { ampicillin } \\
(\mathbf{2 5} \mu \mathrm{g} \text {. disc) }\end{array}$ & $\begin{array}{l}\text { No. resistant } \\
\text { isolates } \\
\text { tested }\end{array}$ & $\begin{array}{l}\text { No. isolates } \\
\text { showing } \\
\text { penicillinase } \\
\text { activity }\end{array}$ \\
\hline Escherichia coli & 427 & $80(19 \%)$ & 15 & $6(40 \%)$ \\
\hline Atypical coli & $\mathbf{2 4}$ & $9(38 \%)$ & 6 & $2(33 \%)$ \\
\hline Proteus spp. & 154 & $62(38 \%)$ & 25 & $9(36 \%)$ \\
\hline Aerobacter aerogenes & 16 & $16(100 \%)$ & 8 & $8(100 \%)$ \\
\hline Pseudomonas aeruginosa & $2 \gamma$ & $27(100 \%)$ & 6 & $3(50 \%)$ \\
\hline
\end{tabular}

\section{Penicillinase activity in naturally resistant Gram-negative organisms}

Gram-negative bacteria isolated from 640 patients with urinary tract infections were examined for resistance by means of discs containing $25 \mu \mathrm{g}$. of antibiotic. A random selection of the organisms found to be resistant were also tested for penicillinase production by the screening method. The results are summarized in Table 4, where it is seen that all strains of Aerobacter aerogenes and a significant proportion of the other organisms showed a definite penicillinase activity. Comparisons made under standard conditions showed that there was considerable variation in the amount of penicillinase produced by different strains. When MIC values for these penicillinase-producing strains were determined by using a standard inoculum of $10^{4}$ bacteria, it was found that the degree of resistance was proportional 
to the amount of penicillinase produced. Table 2 shows this relationship to hold both with naturally resistant organisms and with those selected in the laboratory; also that production of only small amounts of penicillinase was associated with a high degree of resistance in Gram-negative bacteria. It is also seen in Table 2 that Escherichia coli strain CVR 2500, which produced amounts of penicillinase of the same order as a strain of Staphylococcus aureus, required very much larger concentrations of ampicillin to inhibit its growth.

\section{Susceptibility of different penicillins to different penicillinases}

Table 5 shows the susceptibilities of different penicillins to the actions of penicillinases produced by a variety of bacteria when tested under standard conditions at $\mathrm{pH} \mathrm{7.4.} \mathrm{The} \mathrm{penicillinases} \mathrm{of} \mathrm{the} \mathrm{resistant} \mathrm{variant} \mathrm{of} \mathrm{Escherichia} \mathrm{coli} \mathrm{selected} \mathrm{in} \mathrm{the}$ laboratory, and of ampicillin-resistant Gram-negative organisms isolated from patients, inactivated penicillin $\mathbf{G}$ much more readily than ampicillin. Methicillin and BRL 1621 were highly resistant to the action of these penicillinases. The penicillinases produced by Bacillus cereus and Staphylococcus aureus inactivated ampicillin at least as readily as penicillin G. The standard amidase preparation showed properties similar to that of penicillinase from Gram-negative organisms, with the important exception that it was inert against 6-APA. However, 6-APA was less readily inactivated than penicillin $G$ by the other penicillinases tested (Table 5).

Identification of penicillinases. The penicillinases of all the numerous Gramnegative organisms tested were identified as $\beta$-lactamases. These bacteria (from human sources) were tested for amidase activity but none was found.

Table 5. Inactivation of different penicillins by penicillinases of various organisms

\begin{tabular}{|c|c|c|c|c|c|}
\hline \multirow[b]{2}{*}{ Preparation } & \multicolumn{5}{|c|}{$\begin{array}{l}\text { Ratio inactivated relative to penicillin } \mathrm{G} \text { (all at } 0.15 \mathrm{~mm} \\
\text { substrate concentration) }\end{array}$} \\
\hline & $\begin{array}{l}\text { Peni- } \\
\text { cillin G }\end{array}$ & Ampicillin & Methicillin & BRL 1621 & 6-APA \\
\hline Escherichia coli cVR 400 & $\mathbf{1}$ & $0 \cdot 04$ & $<0.001$ & $0 \cdot 002$ & 0.04 \\
\hline E. coli & $\mathbf{1}$ & $0 \cdot 08$ & $<0.001$ & 0.001 & 0.06 \\
\hline Proteus mirabilis & 1 & 0.09 & $<0.001$ & $0 \cdot 003$ & 0.04 \\
\hline Aerobacter aerogenes & 1 & $0 \cdot 05$ & $<0.001$ & $0 \cdot 001$ & 0.03 \\
\hline Staphylococcus aureus & 1 & $1 \cdot 25$ & 0.002 & 0.003 & 0.05 \\
\hline $\begin{array}{l}\text { Standard } \beta \text {-lactamase } \\
(\text { Bacillus cereus } 10 \text { units } / \mathrm{ml} .)\end{array}$ & 1 & $1 \cdot 05$ & $0 \cdot 13$ & 0.2 & $0 \cdot 11$ \\
\hline Standard amidase (from & 1 & $0 \cdot 04$ & 0.002 & $0 \cdot 002$ & $0 *$ \\
\hline
\end{tabular}

* No detectable inactivation

\section{DISCUSSION}

It has been shown that, by serial subculture of three Escherichia coli strains (cv, c 3, $\mathrm{k} 28$ ) in the presence of penicillin $\mathrm{G}$ or ampicillin, variants resistant to both these penicillins could be selected. Resistant variants invariably produced a penicillinase, but apart from the production of this enzyme, no difference could be found between highly ampicillin-resistant variants and their parent strains. The resistance of the 
variants selected was stable after repeated subculture on antibiotic-free media. Of the strains tested, resistant variants were most easily selected from the standard laboratory strain $\boldsymbol{E}$. coli $\mathrm{cv}$. Minute amounts of penicillinase activity were detected in the parent strain of this organism; penicillinase production in the parent strain and its resistant variants was non-inducible. The penicillinase activities of cell-free filtrates of resistant variants of $\boldsymbol{E}$. coli strain cv were proportional to their degree of resistance (Fig. 1; Table 2). Although there was complete cross-resistance between ampicillin-resistant and penicillin G-resistant variants, these variants were no less susceptible to BRL 1621 than was the parent strain (Table 1). It was also found that compound BRL 1621 was resistant to the penicillinase produced by the variants (Table 5). We suggest, therefore, that increased resistance to ampicillin and to penicillin $\mathrm{G}$ was due to the ability of the variants to produce greater amounts of penicillinase.

The degree of ampicillin resistance of several naturally resistant Gram-negative organisms was also found to be proportional to their penicillinase activities (Table 2). However, resistance in some Gram-negative organisms was not associated with penicillinase production (Table 4). Penicillinase production by the penicillinresistant variants of the Gram-negative organisms investigated was small as compared with that by Gram-positive organisms such as the penicillin-resistant staphylococci. The possibility that in resistant variants there was a substantial quantity of bound intracellular penicillinase, not detected by normal testing, was excluded by studying bacteria disrupted by ultrasonic treatment and showing that the bulk of penicillinase was extracellular. It seems, therefore, that in these Gramnegative bacteria a high degree of resistance was conferred by the synthesis of relatively small amounts of penicillinase.

Chemical analysis of cell walls of Gram-negative bacteria has shown marked differences from Gram-positive organisms (Salton, 1953; Cummins \& Harris, 1956). Weidel \& Primosigh $(1957,1958)$ suggested the presence in the Gram-negative cell wall of a layer of lipoprotein lying superficial to the lipopolysaccharide-mucopeptide layer and accounting for $80 \%$ of the wall by weight. Since it is believed that the site of action of penicillin is at the cell membrane (Cooper, 1955), where cell wall synthesis is also thought to occur (Crawthorn \& Hunter, 1958), we suggest that the complex lipid-containing Gram-negative cell wall may form a barrier to the penetration of penicillins. In Gram-positive bacteria, where the cell wall is free from lipid, no such barriers exist. Therefore, penicillin resistance can be more directly related to penicillinase activity on a quantitative basis and relatively much greater amounts of the enzyme are required to confer increased resistance to penicillin (Table 2) than in Gram-negative bacteria.

Kirby (1945) and Luria (1946) suggested that the finding of high values of the minimum inhibitory concentration of antibiotic when using a large inoculum indicates that resistance is due to penicillinase activity. We found that this inoculum effect was much less pronounced with the ampicillin-resistant variants of Escherichia coli strain CV than with a strain of Staphylococcus aureus (Table 3), and therefore in Gram-negative organisms tests based on jnoculum size cannot be relied upon to distinguish between penicillin resistance due to penicillinase production and that from other causes. Again, the explanation for this difference is probably that diffusion of penicillin through the Gram-negative wall was slowed so that the need 
for a large inoculum to destroy penicillin and allow initiation of growth was obviated.

The demonstration of a minute amount of penicillinase activity in the parent Escherichia coli strain cv suggests that resistance was due to small increases in the ability of the variants to produce penicillinase spontaneously in a manner similar to that described by Pollock (1957) for a strain of Bacillus cereus. It is understandable that attempts to demonstrate a similar effect in other Gram-positive bacteria might be difficult, since the degree of increased resistance might be expected to be very small. For example, there has been great difficulty in isolating penicillinase-producing variants from penicillin-sensitive staphylococci in vitro. Barber (1957) was able to demonstrate the slow evolution of strains producing traces of penicillinase by growing staphylococci for long periods in low concentrations of penicillin, although the presence of penicillinase in the parent penicillin-sensitive strains could not be detected.

The finding that ampicillin was more resistant than penicillin $\mathrm{G}$ to the action of the $\beta$-lactamase produced by Gram-negative bacteria is relevant to an explanation for the greater activity of ampicillin against these organisms. However, other factors also determine the activity of a particular penicillin against Gram-negative bacteria, because compound BRL 1621, which was resistant to the action of the $\beta$-lactamase produced by Gram-negative bacteria, was considerably less active than were ampicillin or penicillin $G$ against sensitive organisms. The ability of the penicillin to penetrate the Gram-negative cell wall and then to combine with its specific receptor site are additional factors which must be taken into consideration.

We wish to thank Dr G. N. Rolinson and Dr F. R. Batchelor of Beecham Research Laboratories for technical advice and for the supply of materials.

\section{REFERENCES}

Abraham, E. P. \& Chain, E. (1940). An enzyme from bacteria able to destroy penicillin. Nature, Lond. 146, 837.

BARBer, M. (1957). Drug resistance of staphylococci with special reference to penicillinase production in Drug Resistance in Micro-Organisms, p. 262. CIBA Foundation Symposium: Ed. by G. E. W. Wolstenholme and C. M. O'Connor. London: Churchill.

Batchelor, F. R., Doyle, F. P., Nayler, J. H. C. \& Rolinson, G. N. (1959). Synthesis of penicillin ; 6-aminopenicillanic acid in penicillin fermentations. Nature, Lond. 183, $25 \%$.

Brumfitt, W. \& Heptinstall, R. H. (1960). Experimental pyelonephritis: the relationship of bacterial virulence to the establishment of the renal lesion. Brit. J. exp. Path. 41, 552 .

Cooper, P. D. (1955). The association of the penicillin binding component of Staphylococcus aureus with a lipid fraction. J. gen. Microbiol. 10, 236.

Crawthorn, A. R. \& Hunter, D. G. (1958). Amino acid exchange and protein synthesis in cell walls of Bacillus megaterium. Biochem. J. 69, 47 P.

Cummins, C. S. \& Harris, H. (1956). The chemical composition of the cell wall in some Gram positive bacteria and its possible value as a taxonomic character. J. gen. Microbiol. 14, 583.

Doyle, F. P., Long, A. A. W., Nayler, J. H. C. \& Stove, E. R. (1961). New penicillins stable to both acid and penicillinase. Nature, Lond. 192, 1183.

Duguid, J. P. (1946). Sensitivity of bacteria to the action of penicillin. Edinb. med. J.53, 401. 
Edwardi, P. R. \& Ewing, W. H. (1957). Identification of Enterobacteriaceae, 2nd edition. p. 139. Minneapolis : Burgess Publishing Co.

Haight, T. H. \& Finhand, M. (1952). A modified Got's test for penicillinase production. Amer. J. clin. Path. 22, 806.

Hughes, W. H., Kramer, I. R. H. \& Fleming, A. (1946). The effect of penicillin on morphology. J. gen. Microbiol. 3, xxiii.

KIRBY, W. M. M. (1945). Bacteriostatic and lytic action of penicillin on sensitive and resistant staphylococci. J. clin. Invest. 24, 165.

Knudsen, E. T., Brown, D. M. \& Rolinson, G. N. (1962). A new orally effective penicillinase-stable penicillin-BRL. 1621. Lancet, ii, 632.

LEDERBerg, J. (1957). Mechanism of action of penicillin. J. Bact. 73, 144.

LUria, S. E. (1946). A test for penicillin sensitivity and resistance in staphylococci. Proc. Soc. exp. Biol., N.Y. 61, 46.

Park, J. T. \& Strominger, J. L. (1957). Mode of action of penicillin. Biochemical basis for the mechanism of action of penicillin and for its selective toxicity. Science, 125, 99.

Penret, C. J. (1954). Iodometric assay of penicillinase. Nature, Lond. 174, 1012.

Pollock, M. R. (1957). Penicillin-induced resistance to penicillin in cultures of Bacillus cereus in Drug Resistance in Micro-organisms, p. 78. CIBA Foundation Symposium. Ed. by G.E.W. Wolstenholme and C.M. O'Connor, London: Churchill.

ReEd, L. J. \& Muench, H. (1938). A simple method of estimating 50 per cent end points. Amer. J. Hyg. 27, 493.

Rogers, H. J. \& Mandelstam, J. (1962). Inhibition of cell wall mucopeptide formation in Escherichia coli by benzyl penicillin and 6-[D(-)- $\alpha$-aminophenylacetamido] penicillanic acid (ampicillin). Biochem. J. 84, 299.

Rolinson, G. N., Batchelor, F. R., Butterworth, D., Cameron-Wood, J., Cole, M., Eustace, G. C., Hart, M. V., Richards, M. \& Chain, E. B. (1960). Formation of 6-aminopenicillanic acid from penicillin by enzymic hydrolysis. Nature, Lond. 187, 236.

Rournson, G. N. \& Stevens, S. (1961). Microbiological studies on a new broad spectrum penicillin ('Penbritin'). Brit. med. J. ii, 191.

Salton, M. R. J. (1953). Composition of the cell walls of some Gram positive and Gram negative bacteria. Biochim. biophys. Acta, 10, 512.

SAZ, A. K., Lowery, D. L. \& J ACKson, L. J. (1961). Staphylococcal penicillinase. Inhibition and stimulation of activity. J. Bact. 82, 298.

Weidel, W. \& Primosigh, J. (1957). Die gemeinsame Wurzel der Lyse von $\boldsymbol{E}$. coli $B$ durch Penicillin oder durch Phagen. Z. Naturf. $12 b, 421$.

Weidel, W. \& Primosigh, J. (1958). Biochemical parallels between lysis by virulent phage and lysis by penicillin. J. gen. Microbiol. 18, 513. 